\title{
Short-course high-dose ibuprofen causing both early and delayed jejunal perforations in a non- smoking man
}

\author{
Aseef Yehiyan, ${ }^{1}$ Sowrav Barman, ${ }^{1}$ Haren Varia, ${ }^{2}$ Stephen Pettit ${ }^{1}$
}

\section{'Department of Surgery, Blackpool Teaching Hospitals NHS Foundation Trust, Blackpool, UK \\ ${ }^{2}$ Department of Radiology, Blackpool Teaching Hospitals NHS Foundation Trust, Blackpool, UK}

Correspondence to Stephen Pettit, stephenhpettit@btinternet.com

Accepted 10 December 2017

\section{DESCRIPTION}

A 48-year-old non-smoking man underwent laparotomy for peritonitis immediately after taking ibuprofen $800 \mathrm{mg} 6$ hourly for 14 days for back pain. His only other medication was long-term omeprazole $20 \mathrm{mg}$ per day. At operation he had three separate perforations in his proximal jejunum. Fifteen centimetres of jejunum were resected with primary anastomosis. Histology showed focal mucosal ischaemic changes with normal mucosa between. There was no vasculitis. The perforations were attributed to ibuprofen intake. He made an uneventful recovery and was instructed to refrain from non-steroidal anti-inflammatory drug (NSAID) intake.

He was readmitted 5 months later with abdominal pain. He had continued omeprazole but had taken no further NSAID. CT showed extensive free intra-abdominal fluid with free gas adjacent to his proximal jejunum (figure 1), indicating a further perforation. This was confirmed at laparotomy when a $5 \mathrm{~mm}$ perforated ulcer was found in his proximal jejunum (figure 2). This was repaired and a serosal patch was applied. Histology from the ulcer margin showed ischaemia and infarction (figure 3). He made an uneventful recovery and

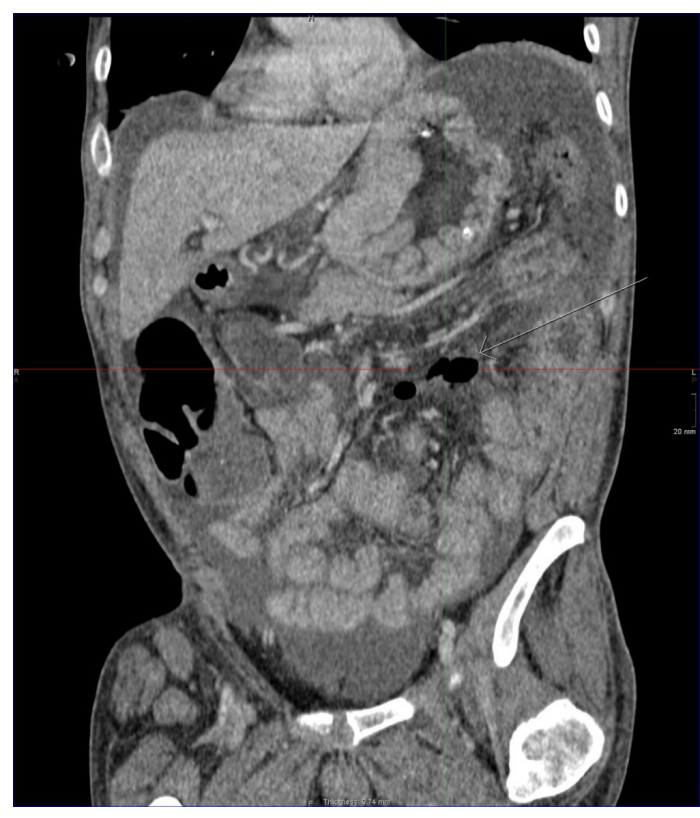

Varia $\mathrm{H}$, et al. BMJ Case Rep Published Online First: [please include Day Month Year]. doi:10.1136/bcr-2017223644
CrossMark

Figure 1 Reformatted coronal CT showing free gas adjacent to the proximal jejunum (arrow) and free fluid in the pelvis.

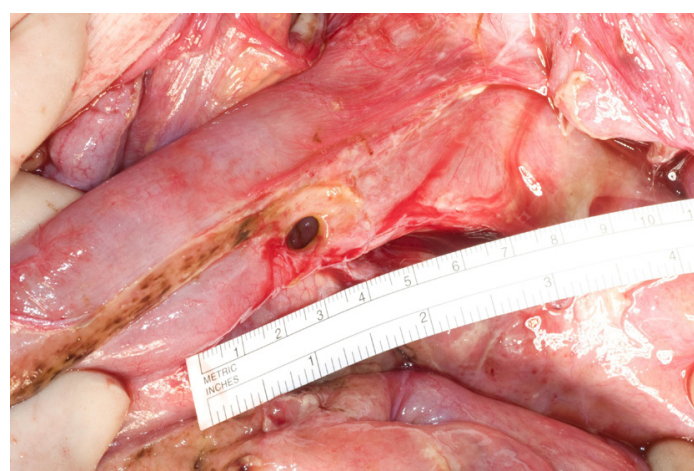

Figure 2 Operative photograph showing the perforated ulcer in the proximal jejunum.

remains well 1 year later. Investigations including serum gastrin, a connective tissue disease screen and thrombophilia screen have been normal, implicating ibuprofen as sole causation for the jejunal ulceration.

Jejunal perforation is a recognised but rare complication of NSAID use ${ }^{12}$ and is reported to occur in $0.0047 \%$ of ibuprofen users. It is known that NSAID can cause small bowel strictures many months after NSAID intake has ceased as a result of an initial microvascular injury to the villous circulation of the small bowel mucosa. ${ }^{3}$ This allows entry of bacteria and their products into the mucosal cells causing further damage. It has recently been reported that the simultaneous use of proton pump inhibition is a risk factor for NSAID-induced small bowel ulceration. ${ }^{4}$ This is because proton pump inhibitors induce changes in the type and numbers of enteral bacteria. A similar mechanism may

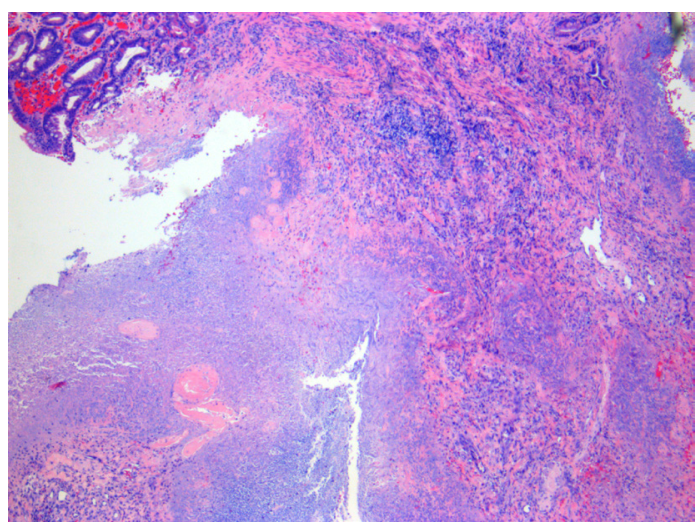

Figure 3 Histopathology slide of jejunum $H \& E \times 50$ magnification showing ulceration and granulation tissue. 
explain this previously unreported occurrence of delayed jejunal perforation following short-course high-dose ibuprofen use.

\section{Learning points}

- Short-course high-dose ibuprofen use can cause both early and delayed jejunal perforations in susceptible individuals.

- Proton pump inhibition exacerbates non-steroidal antiinflammatory drug-induced intestinal damage by inducing dysbiosis.

Contributors AY, SB and SP identified this case as worthy of publication because of its clinical importance. HV undertook the radiological investigations. All the authors were involved in the literature search and in writing up the case report.

Competing interests None declared.
Patient consent Obtained.

Provenance and peer review Not commissioned; externally peer reviewed.

(c) BMJ Publishing Group Ltd (unless otherwise stated in the text of the article) 2017. All rights reserved. No commercial use is permitted unless otherwise expressly granted.

\section{REFERENCES}

1 Risty GM, Najarian MM, Shapiro SB. Multiple indomethacin-induced jejunal ulcerations with perforation: a case report with histology. Am Surg 2007;73:344-6.

2 Kessler WF, Shires GT, Fahey TJ. Surgical complications of nonsteroidal antiinflammatory drug-induced small bowel ulceration. J Am Coll Surg 1997;185:250-4.

3 Sarantitis I, Gerrard AD, Teasdale R, et al. Small bowel diaphragm disease mimicking malignancy. BMJ Case Rep 2015. doi:10.1136/bcr-2015-210174.

4 Washio E, Esaki M, Maehata Y, et al. Proton Pump Inhibitors Increase Incidence of Nonsteroidal Anti-Inflammatory Drug-Induced Small Bowel Injury: A Randomized, Placebo-Controlled Trial. Clin Gastroenterol Hepatol 2016;14:809-15.

Copyright 2017 BMJ Publishing Group. All rights reserved. For permission to reuse any of this content visit

http://group.bmj.com/group/rights-licensing/permissions.

BMJ Case Report Fellows may re-use this article for personal use and teaching without any further permission.

Become a Fellow of BMJ Case Reports today and you can:

- Submit as many cases as you like

- Enjoy fast sympathetic peer review and rapid publication of accepted articles

- Access all the published articles

Re-use any of the published material for personal use and teaching without further permission

For information on Institutional Fellowships contact consortiasales@bmjgroup.com

Visit casereports.bmj.com for more articles like this and to become a Fellow 